\title{
Quantitative Study of Bank-Specific and Social factors of Non-Performing Loans of Pakistani Banking Sector
}

\author{
Hisham UI Hassan ${ }^{a}$, Muhammad llyas ${ }^{b}$, Choudahry Abdul Rehman ${ }^{c}$ \\ Business School, Superior University, Lahore, Pakistan \\ a-cE-mail address: iap@superior.edu.pk,m.ilyas@superior.edu.pk , ceo@superior.edu.pk
}

\begin{abstract}
The Non-Performing loans presented picture of a distorted and slow-paced economy. This issue became more critical when it was observed that NPLs were declining in South East countries except for Pakistan. This study has dual purposes: Firstly to build up a model clarifying the relationship between bank-specific, social factors and non-performing loans. Secondly, to investigate this model in the setting of Pakistani Banking sector as limited interest has been given in existing literature in defining the relationship between bank specific, social factors and non-performing loans. The quantitative methodology is used as it is the most suitable for fulfillment of the study objectives. The results show that various bank-specific factors like credit assessment, credit monitoring and rapid credit growth have significant affect on Non-Performing Loans, whereas interest has a weak significance on NPLs. The social factors including political interference and bankers' incompetence have significant affects on NPLs and these have been important factors in explaining the NonPerforming Loans. This ground-breaking work on Non-Performing Loans and its factors will not only help the entire Pakistani banking sector to control Non-Performing Loans but also its results can be generalized on other countries as well.
\end{abstract}

Keywords: Non-Performing Loans; Bank-Specific Factors; Social factors; Pakistan

\section{INTRODUCTION}

The prime source of incomes of banks is loans and advances. The main objective of banks, like any other business, is to earn and maximize profit so it is understandable that the more the banks will lend the money the more they will earn and the better will be their profitability. But while releasing loans, banks should be very careful and keep a very close eye. It is quite natural that banks try to lend in safe ventures at one hand and to increase the profitability on the other. Therefore the banks must be extremely vigilant when it comes to giving loans at a riskier avenue because the situation can be financially in viable if a large amount of loans default. It can ultimately lead to insolvency of the banks. Even the collateral should be analyzed whether it is given or not.

Saba, Kouser, \& Azeem (2012) are of the view that Non-Performing Loans are so important to study as these are responsible for various financial and economic problems of developed and developing countries. These problems include less per capita income, 
diminishing profits and financial crisis of banking sector. Due to increase in NPLs, the economy of US, which is recognized as a superpower, has gone under the worst crisis of its history. This financial crisis of year 2000 took the entire world in its grip. These NPLs are basically the result of low purchasing power of the borrowers, unproductive use of loans, high interest rates and lenient credit terms of banking sector. So controlling the NPLs can lead to avoid from financial crisis as serious as in the case of US.

The previous studies have shown that the basic factors for determining NPLs are bankspecific and macro-economic factors. The literature of Greece shows that due to favorable macro-economic factors its economy flourished and sustained growth during the mid 90s crisis. But it could not bear the financial crisis of 2007. Due to inefficient management of advancing loans without regard to credibility of borrowers, compromising regulations and socio-economic political pressures, the Greece financial sector took a downturn in the financial crunch of 2007 (Dimitrios P. Louzis, 2012) so this shows that how much banks should be careful about advancing loans. But in case of unfavorable macro-economic situations all efforts of banks in this regard become useless. Therefore, there is a need to deeply look into the macro-economic factors affecting NPLs with utmost care.

There is also literature available which considers bank-specific factors of NonPerforming Loans. According to Badar \& YASMIN JAVID (2013), the role of financial institutions is very important because it uses the amount of depositors in shape of investment. So the decision of investing in a particular venture is the responsibility of that financial institution. If decision is not mature, the loan can turn into a non-performing one. NPLs have been considered as the main reason for financial instability of a country. Sorge (2004) has found NPLs as one of the key reason for the US financial crisis of 2007. NPLs are like a dangerous syndrome which affects two things pretty badly. These two things are profitability and solvency of a financial institution. The bank-specific factor, namely Manager's decision making, has not been given much of importance in the literature.

The basic reason for increasing NPLs in Banks have been the aggressive lending strategies along with less profitability (Reynolds, Ratanakomut and Gander, 2000). Kwack (2000) is of the view that NPLs are the basic reasons behind the crisis of Asian financial markets. During the years 1997 to 1999, the rate of NPLs has shown an increasing trend (from 9\% to 50\%) in Asian countries like Singapore, Hong Kong, Malaysia, Philippines and Taiwan. Therefore if NPLs have gained strength in economy of a particular country in a continent, then it is very difficult for the other countries to ignore these. The NPLs reach at an alarming rate of $23 \%$ in 2003 which shows the inefficiency creeping in Chinese banking sector. Nanto \& Sinha (2002) have termed NPLs as the basic reason behind Asian financial crisis. Hence it can be concluded that even the state-owned banks are not safe from the consequences of NPLs despite of a strong government support from a developed country like China.

The story of Pakistani banking sector does not show a pretty picture either. NPLs have been on a higher side in Pakistani banking sector but recently they have been enormous which is very harmful for economy (Masood, 2009) so there is ominous need to find out the factors affecting NPLs in the context of Pakistani banking sector. The study of Pakistan shows that NPLs are on an increasing trend. Because of high interest rates, borrowing cost increases thus increasing loan defaults (SBP, 2010). On the other hand countries like India, Bangladesh where lending rate show decline. The role of bank-specific and macro-economic factors has been analyzed in the previous studies but political and social factors have not been questioned as yet in Pakistani banking background. 
Previous studies have explained the role of Macro-Economic and Bank Specific determinants of NPLs (Saba, Kouser, \& Azeem, 2012; Badar \& YASMIN JAVID, 2013; Zhang, 2010; Shaer Biabani, 2012). But there is limited number of studies available in the context of Pakistani Banking Sector. In this study the determinants of NPLs are classified into two categories which are Bank Specific and Social. This has not been seen in literature till present date in the context of Pakistani Banking Sector. The review of literature also reveals that there are some variables on which limited research has been done with context of developing countries like Pakistan. These include various Bank Specific variables (Regulatory environment, Corporate Governance) and Social variables (Political instability, Corruption and War on terror) (Khemraj \& Pasha, 2009; Jellouli, 2009; Khan, ur Rehman, Rasli, Khan, \& Mehri).

\section{LITERATURE REVIEW}

Adebola, Wan Yousaff and Dahalan (2011) are of the view that Non-Performing Loans are a big threat not only for a single country but for the whole world as it has been witnessed in case of US financial crisis in recent times. Therefore, it is necessary for the economy for any country that factors of Non-Performing Loans are identified. According to Nkusu (2011), there are two threads of literature about NPLs. One explains relationship between NPLs and its factors, while other links NPLs to financial crisis. It is quite natural that banks try to lend in safe ventures at one hand and to increase the profitability on the other. Therefore, the banks must be extremely vigilant when it comes to giving loans at a riskier avenue.

The study of Ayalew (2009) indicates that the borrowers, even in a developed country, wish to be stated as defaulters. The reason for this is the financial crisis all across the globe adversely affects the capacity of borrowers to repay their loans. In this way the borrowers find a legal way of not returning their debts, thus increasing the amount of Non-Performing Loans. NPLs are realized, as an important factor, being responsible for this financial crisis. The studies of Detraiuche (1998) and Gonzalez-Hermosillo (1999) have supported the phenomena discussed above. According to Javid (2013), the role of financial institutions is very important because it uses the amount of depositors in shape of investment. So the decision of investing in a particular venture is the responsibility of that financial institution. If decision is not mature, the loan can turn into a non-performing one.

\section{1. NPLs In Context Of Pakistani Banking Sector}

NPLs do not directly influence financial crisis in any country but these have a negative impact on economy of a country. This concept is supported by studies of Drees \& Pazrbasioglu (1998) and Kaminsky and Rreinhart (1999). During the years 1997 to 1999, the rate of NPLs has shown an increasing trend (from 9\% to 50\%) in Asian countries like Singapore, Hong Kong, Malaysia, Philippines and Taiwan. NPLs in Pakistan are on a roller coaster ride because according to report of State Bank of Pakistan (SBP), amount of NPLs of banking sector, in the year 2012, has reached to Rs.176.77 billion. Therefore, there is dire need of studying about Non-Performing Loans and its factors. The study of Brownbridge (1998) explains that Non-Performing Loans are one of the chief reasons for the failure of many banks in the world. In addition if these Non-performing Loans are not controlled then the resources of a concern are blocked and thus resulting in low profitability.

Banks in recent years are facing default risk, which is one of the major causes of banks' failure. Pakistani banking sector is facing four types of risks. These are Market risks, Credit 
risks, Liquidity risks and Operational risks. Problem arises when the borrowers fail to return the loans, thus increasing Non-Performing Loans (NPLs) and declining profitability (Haneef, et al., 2012). Therefore, there is a need to study the factors of Non-Performing Loans in setting of Pakistani banking sector.

\section{2. Non-Performing Loans (NPLs)}

There is no specific definition of NPLs to be found in literature. Previous studies have defined NPLs according to their needs. As per Basel committee (2001) NPLs are defined as loans which are not paid and their overdue time period is 90 days after maturity date. NPLs are also explained as "Loans or advances whom credit quality has deteriorated such that full collection of principal and interest in accordance with the loan or advances in repayment terms of the loan or advances in question" (National Bank of Ethiopia). According to SBP (BSD, Circular No. 2 dated June03, 2010), a loan can be divided into three categories. If amount of principal and interest is overdue by 90 days, it will be termed as substandard, if it is overdue by 180 days, it will be termed as doubtful and if it is overdue for a year then a loss. Furthermore if a loan is not paid 30 days after its maturity date, then it is to be considered as NPLs in case of MFBs (Micro Finance Banks) and 90 days in case of consumer financing commercial banks.

\section{3. Bank-Specific and Social Factors of Non-Performing Loans}

\section{3. 1. Bank-specific factors}

There is a lot of literature available on impact of macro-economic factors on NPLs, but fewer studies are available which presents the affect of bank-specific determinants of NonPerforming Loans (NPLs). The banks tend to expand loans in periods of financial stability, so that they can earn more. In this practice they often give an impression of relaxing the lending standards. Therefore, this becomes the reason of loan defaults (Weinberg, 1995). Various researchers have supported this hypothesis (Sinkey, 1992, for US; Salas and Saurina, 2002, for Spain; Bercoff, di Giovanni, Grimard, \& Welcome, 2002).

\section{3. 1. 1. Rapid credit growth and NPLs}

The study of Keeton (1999) shows relationship between loans and speedy credit growth. The author has used a vector auto regression model on commercial banks in United States for the periods 1982-1996. Empirical studies show that lenient credit terms is one of the factors which increases NPLs. Boudriga, Boulila, \& Jellouli (2009) indicate some factors which can reduce NPLs. These factors are foreign capital presence, appropriate capitalization and prudential provisional policy. To expand credit, banks have to ease the standards of credit terms, monitoring of borrowers and decrease the interest rates (Keeton, 1999). The study of Sarlija and Hare (2012) indicates that in case of developed countries, lending is at a much speedy pace. The basic reason is that there are strong legal institutes and laws which give security to the banks against defaults of loans. The study of Jiménez, et al., (2007) points out that herd behavior, moral hazard, agency problems and disaster nearsightedness are the basic factors behind the lenient terms of credit. Furthermore they linked the lenient credit terms with Non-Performing Loans. When the economy is intensifying, bank managers are found to exercise leniency in giving credit because lower credit expansion means lesser income generation which indicates poor performance. 


\subsection{2. Monitoring and NPLs}

The banks, which incur more expenses on monitoring and assessing the borrowers, are less efficient in financial operations but these banks have lower NPLs (Hughes et al, 1996). Various studies show that state-owned banks are less efficient because they concentrate more on monitoring the NPLs. Salas and Saurina (2002) are of the view that inefficient bank management causes NPLs. The loans are more secured if the banks keep a continuous check on the borrowers. The banks need to give their borrowers full attention, so they are not relaxed at any stage about repayment of their loans. It has been seen that less monitoring of borrowers lead to NPLs (Agresti et al, 2008).

There are evidences in literature about poor monitoring, on the part of the banks, to be the main bank-specific factors behind creating NPLs. The banks carry on these practices in order to increase profit (Agresti et al, 2008; Sinkey, 1992, for US; Salas and Saurina, 2002, for Spain). There are also some other features present in them as inadequate monitoring system. The study of Omar (2009) showed that banks are nationalized in the 1970s by the government. The state-owned banks possess $88 \%$ to $96 \%$ of NPLs in the whole banking sector. Due to this poor performance, government reconsidered its thinking. The reforms of 1991 allowed private banks operations in Pakistan. During 1997-2001 the private-owned banks become more strengthened when further reforms are structured to build an extensive and competitive environment.

\subsection{3. Interest and NPLs}

Various researchers have given a variety of findings about this relationship. According to some researchers high interest rate has a significant and positive relationship with NonPerforming Loans. They are of the view that when banks increase interest rate, there is an additional payment burden on borrowers resulting in increased defaults (Stiglitz and Weiss, 1981; Reddy, 2002; Boyd and Nicolo, 2005; Keeton and Morris, 1987; Fofack, 2005; CollinDufresne \& Goldstein, 2001; Asari et al, 2011). Some of studies have also shown a weaker or insignificant relationship between interest rate and Non-Performing Loans (Kaplin et al, 2009; Patnaik and Shah, 2004; Epinoza and Prasad, 2010). The study of Sinkey (2002) shows that increase in interest rate negatively impacts the loan defaults. Similarly the study of Rajan and Dhal (2003) indicates a significant association of high cost of borrowing and Non-Performing Loans (NPLs).

\section{3. 1. 4. Risk assessment and NPLs}

A weak Risk assessment can also play a role in increasing NPLs. The repute of borrowers to repay loan and the market value of securities are not adequately assessed while giving loans which become key reasons behind NPLs (Petersson, 2004). The study of Ning (2007) shows that the banks use their personal experiences in giving loans rather than using historical data, mature credit portfolio management skills and centralized information system. This causes NPLs to grow at even a higher pace. The banks should access information about creditability of the customers, so that NPLs can be reduced. In this regard responsibilities of banks should be clearly defined. It should be ensured that banks exercise effective policies and adequate risk management (Basel, 2001).

The study of Akerlof (1970) explains that due to adverse selection, the borrowers can be differentiated with respect to quality. Low quality borrowers cannot use amount of loan in productive ventures as compared with high quality borrowers. This can result in an increase in NPLs. The Adverse selection problem indicates that when lenders cannot discriminate good 
from bad borrowers, all borrowers are charged a standard interest rate that reveals their collective practice. If this rate is elevated than valuable borrowers justify, it will drive some good borrowers out of the borrowing market, forcing in turn to banks charging even higher rates to the remaining borrowers. That's why the banks prefer to chose high quality borrowers. The selection of borrowers is a challenge in order to control NPLs.

\subsection{Social factors}

If we compare the bank-specific and social factors of Non-Performing Loans in the literature, then we may not find much material relating with the social factors of NPLs. Therefore, this emerges the need to explain the social factors along with bank-specific factors of NPLs. In this way this study will be helpful for the banking sectors of other countries as well because its results can be generalized.

\section{3. 2. 1. Political interference and NPLs}

The commercial banks suffer a great deal when the projects which are being financed by one government face hurdles when there is change of government. In this way the economic growth of the country stops and also the banks have to bear the brunt of that political interference by the new government so due to this government interference the chances of loan default increases (Dinc, 2005). Also the governments tend to favor a particular sector for their personal benefits, ignoring the future prospects, therefore causing Non-Performing Loans for the banks (Chijoriga, 1997).

Khwaja and Mian (2005) present the only empirical study related to information sharing and corruption in setting of Pakistan. This study shows that lending of political firms is $45 \%$ greater than other firms. These political firms incur Non-Performing Loans, 50\% more than any other firms. State-owned banks are main creditors of these political firms as privateowned banks do not take political pressure. The loans of these State-owned banks are turned to bad due to weak implementation of legal framework and political pressure. There is a need to explore the social factors of Non-Performing Loans with reference to Pakistani banking sector, which are missing in previous literature. Therefore, it can be concluded that there is limited Literature available on exploring relationship of NPLs and social factors like political pressure in setting of developing country like Pakistan and certainly indicates a possible gap.

\section{3. 2. 2. Banker's incompetence and NPLs}

According to the study of Masood, Bellalah, \& Mansour (2010), the bankers with high qualification are in a better position to judge the credibility of a customer resulting in decrease in the Non-Performing Loans than one with lower qualification. Simply we can say that qualified and experiened bankers ensure lesser NPLs. De Juan (2003) is of the view that the role played by management in financial crunch is very crucial. Further more if a bank is following the regulatory frame work, coorective actions as per the situations along with proper supervision then the effects of the in efficient management can be neutralised. Mismanagement takes place in two ways; firstly, if the bank and the managerial set up is new; secondly, if the existing management fails to adapt to the changing enviroment of the financial market.

For the financial institutions to survive during the financial crunch, the role of competent bankers who can see the emerging trend of market along with adopting proactive approach, is imperative (Camerer and Johnson, 1997). As per Kim, Michael Chung, \& Paradice (1997) in order to become a competent banker, the employee may be completely 
trained to foresee the financial situation so he can groom himself intellectually to be able to make timely and adequate lending decisions. Therefore, the literature indicates that in today's competitive world banks need such competent bankers who can convert their NPLs in good loans.

\section{THEORETICAL FRAMEWORK AND METHODOLOGY}

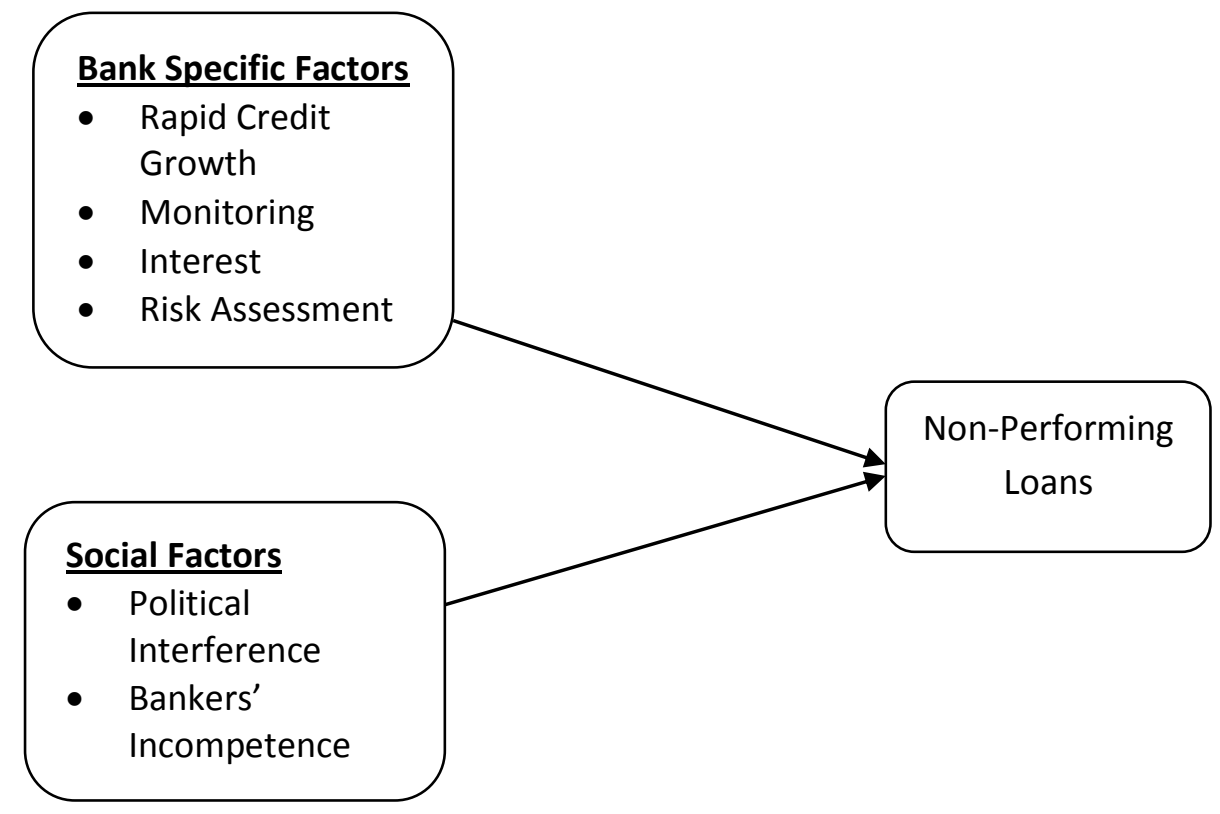

\section{1. Theoretical Framework}

\section{2. Methodology}

This section includes the methods to collect the empirical data on the impact of BankSpecific and Social factors of Non-Performing Loans in Pakistani Banking Sector.

\section{2. 1. Research approach}

Since the objective of my study is to propose and test a model of Bank-specific and Social factors of Non-Performing Loans (NPLs) in the banking sector of Pakistan and to generalize and compare the results through a large sample, therefore, the quantitative methodology is the most suitable for the fulfillment of my study objectives. Quantitative research comprises of various research types such as associational, descriptive and intervention studies. As the purpose of this study is to examine the relationship between Bank-specific, Social factors of Non-Performing Loans, therefore, associational approach will be utilized for the purpose of data analysis. Associational research is basically concerned with examining the relationship between variables. It is further categorized into correlation and causal comparative research (Ary et al., 1996). 


\section{2. 2. Description of sampling}

In the current study randomly selected bank managers from public and private banks of Lahore (Pakistan), having experience of more than five years, are chosen as unit of analysis. The reason for selecting the criteria of minimum five years of experience is to ensure that bankers participating in the research have a clear know how about the Non-Performing Loans and its various factors. The main reason for selecting Lahore as city is that almost all major banks have their branches in it. This study considers top 12 banks on the basis of their assets allocation as per report of State Bank of Pakistan. The next task is to select the minimum sample size for data collection. Some studies consider a range between 50 to 400 as minimum sample size (Aleamoni, 1976). Therefore, in order to cross the minimum sample size requirement 150 randomly selected bank managers and other credit officers will be selected in the province of Punjab and city Lahore.

The following table shows the detail of top ten banks and their assets allocation:

\begin{tabular}{|c|c|c|c|}
\hline Rank & Name of banks & Type & $\begin{array}{c}\text { Assets Allocation } \\
\text { (Million Rs.) }\end{array}$ \\
\hline 1 & NBP & Conventional & $11,53,480$ \\
\hline 2 & HBL & Conventional & $11,39,554$ \\
\hline 3 & UBL & Conventional & $7,53,617$ \\
\hline 4 & MCB Bank Limited & Conventional & $6,53,233$ \\
\hline 5 & Allied Bank Ltd. & Conventional & $5,15,699$ \\
\hline 6 & Bank Alfalah & Conventional & $4,68,173$ \\
\hline 7 & Bank Al Habib & Conventional & $3,84,526$ \\
\hline 8 & Standard Chartered Bank & Conventional & $3,56,405$ \\
\hline 9 & Askari Bank Ltd. & Conventional & $3,43,756$ \\
\hline 10 & Faysal Bank & Conventional & $2,92,568$ \\
\hline 11 & Habib Metropolitan Bank & Conventional & 288,200 \\
\hline 12 & Bank of Punjab & Conventional & 280,998 \\
\hline
\end{tabular}

Source: (Annual Report of Respective Banks, 2011)

\section{2. 3. Instrument of research and issues of validity and reliability}

According to Babbie (2001) the best way to collect data from a large population is Questionnaire. In order to complete the main objective of the study, data is to be gathered for the factors of Non-Performing Loans. The factors include bank-specific factors (Credit Assessment, Credit monitoring, Interest Rate and Rapid Credit Growth) and social factors (Banker's Incompetence and Political Interference). Therefore, the survey questionnaire is divided into two parts. Content validity was ensured in such manner that sample selected comprised of those respondents who had better understanding of the issue of the research. To make sure face validity the researcher executed multi method approach i.e. two or more 
different features measured using two or more diverse approaches. The rationale for using this data collection procedure is that it requires minimum resources as far as staff, time and cost are concerned and also it is best suited confidentiality of information is an issue (Dillman, 2000). The participants have been given due consideration to obtain their agreement on becoming the part of the research procedure by highlighting the need and importance of the issue being question.

\section{DATA ANALYSIS AND RESULTS}

The previous chapters presented the introduction, literature review and the research methodology to be followed. This chapter presents results relating to the bank-specific and social factors affecting the Non-Performing Loans. This chapter tries to show the results of the survey conducted in various banks which are already mentioned previously.

\section{1. Survey Results}

The questionnaire was distributed among bankers which related to the credit department including loan officers, relationship managers, credit managers, credit directors, recovery officers and vice presidents in 12 banks selected from all banks that are operational in Pakistan and registered before the fiscal year 2012-13. The questionnaire was physically distributed to 150 employees which related with credit department. Out of 150 questionnaires 139 were completed and returned. So the overall response was $92-7 \%$ which is impressive if we see it in the context of the research culture in the Pakistan.

Table 1. Survey Response Rate.

\begin{tabular}{|c|c|}
\hline Sample Size & 150 \\
\hline $\begin{array}{c}\text { Completed and returned } \\
\text { questionnaires }\end{array}$ & 139 \\
\hline Response rate & $92.7 \%$ \\
\hline
\end{tabular}

Source: Survey outcome and own computation

\section{1. 1. Respondent's profile}

As far as employment in bank were concerned $91 \%$ of the respondents belonged to private banks whereas remaining $9 \%$ were the employees of state-owned banks.

Table 2. Employment of Respondents.

\begin{tabular}{|c|c|c|}
\hline Employment & Frequency & Percent \\
\hline Private banks & 127 & 91 \\
\hline State-owned banks & 12 & 9 \\
\hline & 139 & 100 \\
\hline
\end{tabular}

Source: Survey outcome and own computation 


\section{1. 2. Respondents' gender}

Out of 139 valid responses, $81.3 \%$ were male and $18.7 \%$ were female. This shows that credit departments of most of the banks are dominated by male officers.

Therefore, it can be inferred that the banks prefer male staff while giving jobs related to loan advancement.

Table 3. Gender of Respondents.

\begin{tabular}{|c|c|c|}
\hline Gender & Frequency & Percent \\
\hline Male & 113 & 81.3 \\
\hline Female & 26 & 18.7 \\
\hline & 139 & 100 \\
\hline
\end{tabular}

Source: Survey outcome and own computation

The survey respondents included $10.8 \%$ loan officers, $36 \%$ relationship managers, $11.5 \%$ credit managers, $20.9 \%$ recovery officers, $16.5 \%$ credit directors and $4.3 \%$ vice presidents.

Table 4. Positions of the respondents in banks.

\begin{tabular}{|c|c|c|}
\hline Positions & Frequency & Percent \\
\hline Loan officers & 15 & 10.8 \\
\hline $\begin{array}{c}\text { Relationship } \\
\text { managers }\end{array}$ & 50 & 36.0 \\
\hline Credit managers & 16 & 11.5 \\
\hline Recovery officers & 29 & 20.9 \\
\hline Credit directors & 23 & 16.5 \\
\hline Vice presidents & 6 & 4.3 \\
\hline
\end{tabular}

Source: Survey outcome and own computation

The survey indicated that by means of experience $28.8 \%$ of the respondents had $11-15$ years of banking experience.

The second larger number of respondents belonged to the category of above 15 years experience as their percentage was $26.6 \%$. Similarly $23.7 \%$ of the respondents belonged to the category of 1-5 years of experience which was the third larger.

The last category with lowest percentage (20.9\%) belonged to 6-10 years of experience. This shows that respondents had vast experience in the banking sector which increased the quality of the survey. 
Table 5. Respondents' experience in the banking sector.

\begin{tabular}{|c|c|c|}
\hline $\begin{array}{c}\text { Years of } \\
\text { experience }\end{array}$ & Frequency & Percent \\
\hline Less than 1 year & --- & --- \\
\hline 1-5 years & 33 & 23.7 \\
\hline 6-10 years & 29 & 20.9 \\
\hline 11-15 years & 40 & 28.8 \\
\hline Above 15 years & 37 & 26.6 \\
\hline
\end{tabular}

Source: Survey outcome and own computation

As from Table 6 we can see that almost majority of the bankers related to credit department are highly qualified. This can be seen from the below table in which most of respondents are above Bachelor level.

Table 6. Qualification of the Respondents.

\begin{tabular}{|c|c|c|}
\hline & Frequency & Percent \\
\hline MPhil/ PHD & 6 & 4.3 \\
\hline Master Degree & 120 & 86.3 \\
\hline Bachelor Degree & --- & --- \\
\hline Others & 13 & 9.4 \\
\hline
\end{tabular}

\section{2. Factors affecting the Non-Performing Loans}

The core objective of this study was to assess the bank-specific and social factors affecting the Non-Performing Loans. The study required respondents to show their agreement and disagreement to certain statements which were related with bank-specific and social factors of Non-Performing Loans. The following table depicts responses on the relationship between credit assessment and Non-Performing Loans.

Table 7. Factors indicating relation between credit assessment and NPLs.

\begin{tabular}{|c|c|c|c|c|c|c|c|}
\hline & $\begin{array}{c}\text { Strongly } \\
\text { Agree } \\
(\%)\end{array}$ & $\begin{array}{c}\text { Agree } \\
(\%)\end{array}$ & $\begin{array}{c}\text { Neutral } \\
(\%)\end{array}$ & $\begin{array}{c}\text { Disagree } \\
(\%)\end{array}$ & $\begin{array}{c}\text { Strongly } \\
\text { Disagree } \\
(\%)\end{array}$ & Mean & $\begin{array}{c}\text { Standard } \\
\text { Deviation }\end{array}$ \\
\hline $\begin{array}{c}\text { The borrowers, which } \\
\text { are admitted by } \\
\text { compromising the } \\
\text { assessment conditions } \\
\text { usually default. }\end{array}$ & 35.3 & 54.0 & 8.6 & 2.2 & --- & 4.22 & 0.692 \\
\hline
\end{tabular}




\begin{tabular}{|c|c|c|c|c|c|c|c|}
\hline $\begin{array}{c}\text { If the bank knows } \\
\text { about the customers' } \\
\text { previous credit history, } \\
\text { it will lead to high } \\
\text { loans quality. }\end{array}$ & 33.8 & 54.0 & 12.2 & --- & -- & 4.22 & 0.646 \\
\hline $\begin{array}{c}\text { Good loan } \\
\text { understanding ensures } \\
\text { loan. }\end{array}$ & 23.0 & 48.2 & 25.2 & 3.6 & --- & 3.91 & 0.788 \\
\hline $\begin{array}{c}\text { Poor risk assessment } \\
\text { would lead to loan } \\
\text { defaults. }\end{array}$ & 24.5 & 48.2 & 23.7 & 3.6 & --- & 3.94 & 0.791 \\
\hline
\end{tabular}

Source: Survey outcome and own computation

The above table shows that $89.3 \%$ respondents agree that the borrowers admitted compromising the assessment conditions becomes one of the reasons for occurrence of NonPerforming Loans with a mean response of 4.22 and standard deviation of 0.692 . On the other side $87.8 \%$ of respondents agree that if the bank knows about the previous credit history of the customers, it can increase the quality of loan (mean 4.22 and standard deviation 0.646). As far as good loan understanding is concerned $71.2 \%$ of respondents agree that it is important in ensuring loan collection.

Tight monitoring of loan can enhance its quality. This has been acknowledged by $68.4 \%$ of the respondents (mean 3.87 and standard deviation 0.779 ). $72.7 \%$ of the respondents agree that credit monitoring is directly related with occurrence of NPLs. Therefore, we can say that credit monitoring is directly related to the performance of loans. These can be seen through figures of the following table:

Table 8. Factors indicating credit monitoring and NPLs.

\begin{tabular}{|c|c|c|c|c|c|c|c|}
\hline & $\begin{array}{c}\text { Strongly } \\
\text { Agree } \\
(\%)\end{array}$ & $\begin{array}{c}\text { Agree } \\
(\%)\end{array}$ & $\begin{array}{c}\text { Neutral } \\
(\%)\end{array}$ & $\begin{array}{c}\text { Disagree } \\
(\%)\end{array}$ & $\begin{array}{c}\text { Strongly } \\
\text { Disagree } \\
(\%)\end{array}$ & Mean & $\begin{array}{c}\text { Standard } \\
\text { Deviation }\end{array}$ \\
\hline $\begin{array}{c}\text { Strict monitoring of loans } \\
\text { ensures improved loan } \\
\text { performance. }\end{array}$ & 21.6 & 46.8 & 28.8 & 2.9 & -- & 3.87 & 0.779 \\
\hline $\begin{array}{c}\text { Properly monitoring of a } \\
\text { weak loan or advance can } \\
\text { decrease the chances of its } \\
\text { default. }\end{array}$ & --- & 5.0 & 19.4 & 29.5 & 46 & 1.83 & 0.912 \\
\hline $\begin{array}{c}\text { Credit monitoring is } \\
\text { directly related with the } \\
\text { occurrence of NPLs. }\end{array}$ & 29.5 & 43.2 & 26.6 & 0.7 & -- & 4.01 & 0.771 \\
\hline $\begin{array}{c}\text { If bank spends more on } \\
\text { credit monitoring, it can } \\
\text { lower the level of NPLs. }\end{array}$ & 20.1 & 30.2 & 40.3 & 7.9 & 1.4 & 3.60 & 0.946 \\
\hline
\end{tabular}

Source: Survey outcome and own computation 
Table 9. Factors indicating relation between Interest and NPLs.

\begin{tabular}{|c|c|c|c|c|c|c|c|}
\hline & $\begin{array}{c}\text { Strongly } \\
\text { Agree } \\
(\%)\end{array}$ & $\begin{array}{c}\text { Agree } \\
(\%)\end{array}$ & $\begin{array}{c}\text { Neutral } \\
(\%)\end{array}$ & $\begin{array}{c}\text { Disagree } \\
(\%)\end{array}$ & $\begin{array}{c}\text { Strongly } \\
\text { Disagree } \\
(\%)\end{array}$ & Mean & $\begin{array}{c}\text { Standard } \\
\text { Deviation }\end{array}$ \\
\hline $\begin{array}{c}\text { Loans having interest } \\
\text { have more chances to } \\
\text { turn to NPL. }\end{array}$ & 0.7 & 9.4 & 28.8 & 35.3 & 25.9 & 2.24 & 0.967 \\
\hline $\begin{array}{c}\text { If high interest rates are } \\
\text { charged it can lead to } \\
\text { loan default. }\end{array}$ & 19.4 & 30.9 & 28.8 & 11.5 & 9.4 & 3.40 & 1.196 \\
\hline $\begin{array}{c}\text { Interest charged on loan } \\
\text { affects the performance } \\
\text { of loans. }\end{array}$ & 15.8 & 52.5 & 23.0 & 7.9 & 0.7 & 3.75 & 0.843 \\
\hline
\end{tabular}

Source: Survey outcome and own computation

The above table shows that only $10.1 \%$ of respondents (mean 2.24 and standard deviation 0.967) agree that loan due to charging interest can turn a loan into NPLs whereas $50.3 \%$ of respondents have the belief that high interest rate can increase Non-Performing Loans. Therefore, it can be concluded that interest has not a very strong relation with NonPerforming Loans. Table 10 indicates about the responses generated for describing the relation between rapid credit growth and Non-Performing Loans.

Table 10. Factors indicating the relation between Rapid Credit Growth and NPLs.

\begin{tabular}{|c|c|c|c|c|c|c|c|}
\hline & $\begin{array}{c}\text { Strongly } \\
\text { Agree } \\
(\%)\end{array}$ & $\begin{array}{c}\text { Agree } \\
(\%)\end{array}$ & $\begin{array}{c}\text { Neutral } \\
(\%)\end{array}$ & $\begin{array}{c}\text { Disagree } \\
(\%)\end{array}$ & $\begin{array}{c}\text { Strongly } \\
\text { Disagree } \\
(\%)\end{array}$ & Mean & $\begin{array}{c}\text { Standard } \\
\text { Deviation }\end{array}$ \\
\hline $\begin{array}{c}\text { Aggression in giving } \\
\text { loans can lead to higher } \\
\text { NPLs. }\end{array}$ & 41.0 & 52.5 & 5.8 & 0.7 & --- & 4.34 & 0.620 \\
\hline $\begin{array}{c}\text { There are more chances } \\
\text { of high NPLs if } \\
\text { advancement of credit } \\
\text { by bank is rapid. }\end{array}$ & 40.3 & 43.2 & 16.5 & --- & --- & 4.242 & 0.718 \\
\hline $\begin{array}{c}\text { If integrity in lending is } \\
\text { compromised, it can } \\
\text { lead to loan defaults. }\end{array}$ & 25.9 & 43.9 & 28.1 & 2.2 & --- & 3.94 & 0.791 \\
\hline $\begin{array}{c}\text { Giving loans to a large } \\
\text { number of borrowers } \\
\text { can increase chances of } \\
\text { NPLs. }\end{array}$ & 26.6 & 46.8 & 20.9 & 5.8 & --- & 3.94 & 0.841 \\
\hline $\begin{array}{c}\text { If the bank has the } \\
\text { tendency of taking } \\
\text { greater risks then this } \\
\text { can increase NPLs. }\end{array}$ & 41.0 & 52.5 & 5.8 & 0.7 & --- & 3.73 & 0.750 \\
\hline
\end{tabular}

Source: Survey outcome and own computation 
Table 11. Factors indicating the relation between Political Interference and NPLs.

\begin{tabular}{|c|c|c|c|c|c|c|c|}
\hline & $\begin{array}{c}\text { Strongly } \\
\text { Agree } \\
(\%)\end{array}$ & $\begin{array}{c}\text { Agree } \\
\text { (\%) }\end{array}$ & $\begin{array}{c}\text { Neutral } \\
\text { (\%) }\end{array}$ & $\begin{array}{c}\text { Disagree } \\
\text { (\%) }\end{array}$ & $\begin{array}{c}\text { Strongly } \\
\text { Disagree } \\
(\%)\end{array}$ & Mean & $\begin{array}{c}\text { Standard } \\
\text { Deviation }\end{array}$ \\
\hline $\begin{array}{c}\text { Political interference } \\
\text { in the lending decision } \\
\text { is a cause of NPLs in } \\
\text { Pakistan. }\end{array}$ & 42.4 & 48.2 & 7.9 & 1.4 & -- & 4.32 & 0.681 \\
\hline $\begin{array}{c}\text { Political pressurized } \\
\text { bank authorities ready } \\
\text { to extend credit } \\
\text { facilities without } \\
\text { completing } \\
\text { satisfactory } \\
\text { requirements may } \\
\text { cause bad loans. }\end{array}$ & 38.1 & 48.2 & 12.2 & 0.7 & 0.7 & 4.22 & 0.743 \\
\hline $\begin{array}{c}\text { Strategic planning } \\
\text { without considering } \\
\text { the business } \\
\text { community is also } \\
\text { causing NPLs in } \\
\text { Pakistan. }\end{array}$ & 19.4 & 41.7 & 33.1 & 5.0 & 0.7 & 3.74 & 0.854 \\
\hline $\begin{array}{c}\text { Disbursement of loans } \\
\text { to politicians under } \\
\text { political pressure is } \\
\text { causing NPLs in } \\
\text { Pakistan. }\end{array}$ & 60.4 & 20.1 & 6.5 & 5.0 & 7.9 & 4.20 & 1.246 \\
\hline
\end{tabular}

Source: Survey outcome and own computation

The above table shows that $90.6 \%$ of respondents (mean 4.32 and standard deviation 0.681) strongly agree that political interference in the lending decision is a cause of NPLs in Pakistan. In addition 53.4\% of respondents agree that due to political pressure bank authorities compromise the terms of loan advancement which causes bad loans.

Lastly lets analyze the responses about the relation between bankers' incompetence and NPLs. As per table 13, 82.8\% of respondents believe that lending officer's qualification plays a key role in making wise loan decisions. 
Table 12. Factors indicating the relation of factors of Bankers' Incompetence and NPLs.

\begin{tabular}{|c|c|c|c|c|c|c|c|}
\hline & $\begin{array}{c}\text { Strongly } \\
\text { Agree } \\
(\%)\end{array}$ & $\begin{array}{c}\text { Agree } \\
(\%)\end{array}$ & $\begin{array}{c}\text { Neutral } \\
(\%)\end{array}$ & $\begin{array}{c}\text { Disagree } \\
(\%)\end{array}$ & $\begin{array}{c}\text { Strongly } \\
\text { Disagree } \\
(\%)\end{array}$ & Mean & $\begin{array}{l}\text { Standard } \\
\text { Deviation }\end{array}$ \\
\hline $\begin{array}{l}\text { Lending officer's } \\
\text { qualification plays a key } \\
\text { role in making wise } \\
\text { loaning decisions. }\end{array}$ & 46.8 & 36.0 & 12.9 & 4.3 & --- & 4.25 & 0.844 \\
\hline $\begin{array}{l}\text { Lending officer's } \\
\text { experience in the service } \\
\text { and his experience in } \\
\text { dealing with the lending } \\
\text { matter's plays an } \\
\text { important role in making } \\
\text { wise loaning decisions. }\end{array}$ & 58.3 & 39.6 & 2.2 & --- & --- & 4.56 & 0.540 \\
\hline $\begin{array}{l}\text { Good and up to date } \\
\text { training of banker's plays } \\
\text { a very important and key } \\
\text { role in their professional } \\
\text { grooming and enables } \\
\text { them to make wise loaning } \\
\text { decisions. }\end{array}$ & 36.0 & 44.6 & 18.7 & 0.7 & --- & 4.16 & 0.745 \\
\hline $\begin{array}{l}\text { If a lending officer is } \\
\text { groomed in good } \\
\text { supervision, trained well } \\
\text { and is involved in lending } \\
\text { decisions, on the basis of } \\
\text { this exposure he/she can } \\
\text { make wise lending } \\
\text { decisions. }\end{array}$ & 51.8 & 38.8 & 7.9 & 0.7 & 0.7 & 4.40 & 0.730 \\
\hline $\begin{array}{l}\text { Manager's capability to } \\
\text { with stand the pressure } \\
\text { (pressure from customer } \\
\text { and higher authorities) } \\
\text { plays an important role in } \\
\text { making wise loan } \\
\text { decisions. }\end{array}$ & 49.6 & 36.9 & 10.8 & 2.9 & --- & 4.33 & 0.784 \\
\hline
\end{tabular}

Source: Survey outcome and own computation

\section{DISCUSSION OF THE RESEARCH FINDINGS}

The main objective of this study was to identify the bank-specific and social factors of Non-Performing Loans (NPLs). This study has analyzed the affect of each factor on NPLs. The spotlight of this study is to discuss the bank-specific and social factors of NPLs. In this regard the questions asked in the questionnaire pointed out bank-specific factors like Rapid Credit Growth, poor Monitoring, Interest and weak Risk Assessment and social factors like 
Political Interference and Bankers' Incompetence to be the causes of NPLs. These were further investigated in this study.

\section{1. Credit Assessment and NPLs}

This study showed that $44 \%$ respondents agreed that a loan defaults if the borrowers are admitted by compromising the assessment conditions. The study also highlighted that if the bank has strong knowledge about the credit history of a borrower then this would lead to high loan quality. Furthermore the study also indicated that poor risk assessment can also lead to high NPLs as $97.2 \%$ of respondents agreed on that statement in the survey conducted. The five Cs (Character, Condition, Collateral, Capital and Capacity) are considered basic tools before lending. In case of failure to conduct adequate risk assessment would lead to missing any or all of the five Cs resulting in loan defaults. These survey results have been supported in the literature. Ning (2007) pointed out that poor risk assessment has an impact on the quality of loan.

\section{2. Monitoring and NPLs}

The survey results showed that $92.7 \%$ of the respondents agreed that tight monitoring of loans enhance its quality. This has been verified in the literature as Agresti et al (2008) stated that regular and adequate monitoring of a loan would result in Non-Performing Loans. The survey results also show that if a loan is poorly assessed then it can be avoided from default by adequate monitoring. The results also indicate that credit monitoring directly affects the occurrence of NPLs. However, survey also indicates that if banks spend more on monitoring the loans then it is not guaranteed that level of NPLs may decrease. The previous studies also support this as Salas and Saurina (2002) are of the view that the loans are more secured if the banks keep a continuous check on the borrowers.

\section{3. Interest and NPLs}

Various researchers have given different findings about the relationship between interest and NPLs. Some researchers find a significant and positive relationship between interest and NPLs (Khemraj and Pasha 2009; Fofack 2005). They are of the view that when banks increase interest rate there is an additional burden on borrowers due to which chances of loan default increase. Some studies have shown a weaker or insignificant relationship between NPLs and interest (Kaplin et al 2009). This survey does not indicate a very strong relation between interest and NPLs as only $10.1 \%$ of respondents agree that interest can turn a loan into non-performing. Similarly, $50.3 \%$ of respondents believe that high interest rate can lead to loan defaults, which is not a very high percentage. Therefore, the results of the study match with the literature that supports a weak relation between interest and NPLs.

\section{4. Rapid Credit Growth and NPLs}

The survey results indicate that rapid credit growth is connected with NPLs as $83.5 \%$ of the respondents agree that there are more chances of high NPLs if advancement of credit by banks is rapid. Furthermore, $93.5 \%$ of the respondents consider aggression in giving loans as a strong reason behind NPLs. Likewise, respondents also believe that if integrity is compromised in giving loans or there is large number of borrowers or there is tendency of bank to take greater risks, can lead to higher NPLs. This result has been supported by the studies of Berger and De Young (1997) and Pain (2003). 


\section{5. Political Interference and NPLs}

The literature shows that political interference has a significant impact on NPLs. The study of Chijoriga (1997) specifies that when government tends to favor a particular sector for its personal benefits, ignoring the future prospects resulting in occurrence of NPLs for the banks. The study of Khawaja and Mian (2005) reveals that majority of loans taken by the political firms in Pakistan, due to political pressure, are defaulted. The results of this study are quite similar as $90.6 \%$ of the respondents agree that political interference in the lending decisions is a cause of NPLs in Pakistan. Majority of the respondents also agree that if terms of loan advancement are compromised then it can lead to even higher NPLs. In addition the respondents strongly believe that loans being disbursed under political pressure to politicians causes NPLs in Pakistani banking sector. However only $19.4 \%$ of respondents strongly agree that strategic planning without considering the business community is causing NPLs in Pakistan.

\section{6. Bankers' Incompetence and NPLs}

The survey results show that respondents consider bankers' incompetence, another factor, affecting NPLs. As per Table 12, 82.8\% of the respondents agree that lending officers' qualification play a key role in making wise loan decisions possible. $58.3 \%$ of the respondents strongly agree that lending officers' experience in dealing with loan advancement matters take active part in making appropriate lending decisions. In addition majority of the respondents also agree that up to date training, grooming, exposure and capability to sustain pressure also play a vital role in making prudent loan decisions. These all factors altogether lead to an increase in quality of loans. The literature indicates that in today's competitive environment, banks need such competent bankers who can convert their NPLs into performing ones. According to the study of Masood, Bellalah and Mansour (2010) the bankers with high qualification are in a better position to judge the credibility of a loan resulting in lesser levels of NPLs than ones with lower qualification.

\section{RECOMMENDATIONS, CONCLUSION, FUTURE RESEARCH PERSPECTIVES AND LIMITATIONS}

After the detailed examination and analysis of the research finding the following recommendation are suggested:

1. Bank should have such mechanisms that can ensure the verification of five C's before lending loans. These five C's include condition, collateral, capital, and character.

2. Banks should ensure the following of the adequate monitoring system which should start before giving loans by identifying the status of a borrower and should continue until and unless the loan is matured.

3. Bank should realize that before monitoring of loan, its adequate assessment is necessary. Therefore, latest assessment procedure should be adopted on selection of customers, credit analysis and sanctioning process.

4. Bank should follow a balanced policy between profit maximization and risk taking. It should be ensured that bank may not enter in an unhealthy and unnecessary risky competition.

5. The Banks should be properly supervised and guided about the regulations in loan disbursement process by State bank. Prudence of policies that govern bank loans 
should continuously be ensured along with comparison with international processes, macroeconomic conditions and level of development of banks and the economy by the State bank of Pakistan.

6. There is a need to educate the Pakistan banking sector to conduct various training programs for the bankers who are involved in lending process. Also the banks should be given awareness about the consequences of rapid credit disbursement in order to improve quality of loans.

7. The banks' management should be made so much autonomous that it could work independently without taking any pressure weather it's from inside i.e. owners or outside i.e. political.

8. The government should play a positive role in ensuring that politicians do not pressurize or influence the loan advancement decision of banks especially the state owned banks.

\section{1. CONCLUSIONS}

The extensive objective of this research was to determine the bank-specific and social factors of NPLs. On the basis of this, various number of precise research questions were developed. To fulfill the main objective the study used quantitative research approach. More exclusively the study used survey of banks' employees dealing with loan advancement and decision making. From the views of respondents, the results show the following factors affecting the occurrence of Non-Performing Loans (NPLs) in Pakistani banking sector:

The study has indicated that the borrowers which are admitted by compromising the assessment conditions, banks' knowledge about the previous credit history of customers, good understanding of loans and poor risk assessment have caused impact on NPLs. The research also shows that strict monitoring of loans has an impact on NPLs. The results also point out that if a loan is not properly assessed then it can turn into NPLs even if it is appropriately monitored. The study further explained that interest has a weak relation with NPLs and not an important factor affecting the former. In addition the study also reveals that rapid credit growth has a significant impact on NPLs. This research shows that due to competition, terms of loans are compromised or riskier investment options are utilized by the banks which cause NPLs.

Along with bank-specific factors, social factors are also identified in this research. The study indicates a strong relation of bankers' incompetence and political interference with NPLs. This research shows that banks do get pressurized under political influence and compromise credit terms leading to NPLs. Furthermore, research results show that proper trained and qualified bankers increase quality of loans.

\section{2. Future research perspectives:}

1. There is a need of mixed approach using quantitative as well as qualitative approaches while determining the factors of NPLs.

2. Various factors of NPLs like war on terrorism, corporate governance on NPLs still needed to be explored.

3. NPLs may be classified into various classes and each class's factors can be determined separately.

4. More social factors affecting NPLs needed to be investigated e.g. legal system, corruption etc. 


\section{3. Limitations}

1. This study was based on collecting survey questionnaires only from Lahore.

2. Some of the questions in the questionnaire were related to sensitive issues like political interference, so the information collected may be biased.

\section{References}

[1] Abedola, S., Wan Yusoff, W., \& Dalahan, J. (2011). An ARDL approach to the determinants of nonperforming loans in Islamic banking system in Malaysia. Kuwait Chap Arabian J Bus Manag Rev, 1(1), 20-30.

[2] Agresti, A.-M., Baudino, P., \& Poloni, P. (2008). The ECB and IMF Indicators for the Macro-prudential Analysis of the Banking Sector: European Central Bank.

[3] Akerlof G.A. (1970). The Market for "Lemons": Quality Uncertainty and the Market Mechanism; The Quaterly Journal of Economics 84(3).

[4] Aleamoni, L. M. (1976). 'The relation of sample size to the number of variables in suing factor analysis techniques'. Educational and Psychological Measurement, 36, 879-883

[5] Ary, D., Jacobs, L., \& Razavieh, A. (1996). Introduction to research in education. Orlando, Florida: Holt, Rinehart and Winston: Inc.

[6] Asari, F., Muhamad, N., Ahmad, W., Latif, N., Addullah, N., \& Jusoff, K. (2011). An Analysis of Non-Performing Loan, Interest Rate and Inflation Rate Using Stata Software. World Applied Sciences Journal, 12, 41-48.

[7] Ayalew, T. (2009). SCHOOL OF LAW. Addis Ababa University.

[8] Babbie, E. R. (2001). The Practice of Social Research (Belmont, CA: Wadsworth Thomson Learning, 9th edn).

[9] Badar, M., \& Yasmin Javid, A. (2013). Impact of Macroeconomic Forces on Nonperforming Loans: An Empirical Study of Commercial Banks in Pakistan. WSEAS Transactions on Business \& Economics, 10(1).

[10] Basel Committee. (2001). Sound Practices for the Management and Supervision of Operational Risk. Basel Committee on Banking Supervision.

[11] Bercoff, J. J., di Giovanni, J., Grimard, F., \& Welcome, P. A. C. (2002). Argentinean Banks, Credit Growth and the Tequila Crisis: A Duration Analysis. Unpublished Paper.

[12] Bonilla, C. A. O. (2011). Macroeconomic determinants of the Non-Performing Loans in Spain and Italy. University of Leicester.

[13] Boudriga, A., Taktak, N. B., \& Jellouli, S. (2009a). Bank specific, business and institutional environment determinants of nonperforming loans: Evidence from MENA countries. Paper for ERF conference on «Shocks, Vulnerability and Therapy», Cairo, Egypt.

[14] Boudriga, A., Taktak, N. B., \& Jellouli, S. (2009b). Banking supervision and nonperforming loans: a cross-country analysis. Journal of financial economic policy, $1(4), 286-318$. 
[15] Boyd, J. H., \& De Nicolo, G. (2005). The theory of bank risk taking and competition revisited. The journal of finance, 60(3), 1329-1343.

[16] Brownbridge, M. (1998). The causes of financial distress in local banks in Africa and implications for prudential policy.

[17] Camerer, C. F., \& Johnson, E. J. (1997). 10 The process-performance paradox in expert judgment: How can experts know so much and predict so badly? Research on judgment and decision making: Currents, connections, and controversies, 342.

[18] Chijoriga, M. (1997). Application of credit scoring and financial distress prediction models to commercial banks lending: the case of Tanzania. Wirts Chaftsnnversitat Wien (WU), Vienna.

[19] Collin-Dufresne, P., \& Goldstein, R. S. (2001). Do credit spreads reflect stationary leverage ratios? The journal of finance, 56(5), 1929-1957.

[20] De Juan, A. (2003). From good bankers to bad bankers: Ineffective supervision and management deterioration as major elements in banking crises. Journal of Banking Regulation, 4(3), 237-246

[21] Dillman, D. A. (2000). Mail and internet surveys: The tailored design method (Vol. 2): Wiley New York.

[22] Dinc, I. S. (2005). Politicians and banks: Political influences on government-owned banks in emerging markets. Journal of Financial Economics, 453-479.

[23] Drees, B., \& Pazarbasioglu, C. (1998). The Nordic banking crises: pitfalls in financial liberalization?: International monetary fund.

[24] Espinoza, R. A., \& Prasad, A. (2010). Nonperforming loans in the GCC banking system and their macroeconomic effects: International Monetary Fund.

[25] Fofack, H. (2005). Nonperforming loans in Sub-Saharan Africa: causal analysis and macroeconomic implications. World Bank Policy Research Working Paper (3769).

[26] Gonzalez-Hermosillo, B. (1999). Determinants of ex-ante banking system distress: a macro-micro empirical exploration of some recent episodes: International Monetary Fund.

[27] Hughes, J. P., Lang, W., Mester, L. J., \& Moon, C.-G. (1996). Efficient banking under interstate branching. Journal of Money, Credit and Banking, 1045-1071.

[28] Saba, I., Kouser, R., \& Azeem, M. (2012). Determinants of Non Performing Loans: Case of US Banking Sector. The Romanian Economic Journal, Year XV(44).

[29] Jiménez, G., Ongena, S., Peydro-Alcalde, J. L., \& Saurina, J. (2007). Hazardous times for monetary policy: what do twenty-three million bank loans say about the effects of monetary policy on credit risk?: Centre for Economic Policy Research.

[30] Kaminsky, G. L., \& Reinhart, C. M. (1999). The twin crises: the causes of banking and balance-of-payments problems. American economic review, 473-500.

[31] Kaplin, A., Levy, A., Qu, S., Wang, D., Wang, Y., \& Zhang, J. (2009). The relationship between default risk and interest rates: An empirical study. Moody's Analytics, Moody's KMV Company. 
[32] Keeton, W. R. (1999). Does faster loan growth lead to higher loan losses? Economic Review-Federal Reserve Bank Of Kansas City, 84, 57-76.

[33] Keeton W. \& C. S. Morris (1987). Why Do Banks' Loan Losses Differ? Federal Reserve Ban of Kansas City, Economic Review, May, pp. 3-21.

[34] Khan, H., ur Rehman, S., Rasli, A. M., Khan, F., \& Mehri, M. Political Risk and Some Other Factors Causing Non-Performing Loans in Pakistan: An Empirical Study of Pakistani Commercial Banks.

[35] Khemraj, T., \& Pasha, S. (2009). The determinants of non-performing loans: an econometric case study of Guyana.

[36] Khwaja, A. I., \& Mian, A. (2005). Do lenders favor politically connected firms? Rent provision in an emerging financial market. The Quarterly Journal of Economics, 120(4), 1371-1411.

[37] Kim, C. N., Michael Chung, H., \& Paradice, D. B. (1997). Inductive modeling of expert decision making in loan evaluation: a decision strategy perspective. Decision Support Systems, 21(2), 83-98.

[38] Kwack, S. Y. (2000). An empirical analysis of the factors determining the financial crisis in Asia. Journal of Asian Economics, 11(2), 195-206.

[39] Masood, O. (2009). Determinants of Non-performing Bank Loans and Bank Loan Recovery in Pakistan A survey approach. Euro-Mediterranean Economics And Finance Review, 89-104.

[40] Masood, O., Bellalah, M., \& Mansour, W. (2010). Non-performing bank loans and Credit Managers' Role:A Comparative Approach from Pakistan and Turkey. International Journal Of Business, 15(3), 347-362.

[41] Nanto, D. K., \& Sinha, R. (2002). China's banking reform. Post-Communist Economies, $14(4), 469-493$.

[42] Nkusu, M. (2011). Nonperforming loans and macrofinancial vulnerabilities in advanced economies. IMF Working Papers, 1-27.

[43] Pain, D. (2003). The provisioning experience of the major UK banks: a small panel investigation: Bank of England.

[43] Patnaik, I., \& Shah, A. (2004). Interest rate volatility and risk in Indian banking (Vol. 4): International Monetary Fund.

[44] Petersson, J., \& Wadman, I. (2004). Non Performing Loans-the markets of Italy and Sweden.

[45] Rajan, R., \& Dhal, S. C. (2003). Non-performing loans and terms of credit of public sector banks in India: An empirical assessment. Occasional Papers, 24(3), 81-121.

[46] Reddy, P. K. (2002). A comparative study of Non-performing assets in India in the Global contextsimilarities and dissimilarities, Remedial measures. Retrieved on March, 23,2012

[47] Reynolds, S. E., Ratanakomut, S., \& Gander, J. (2000). Bank financial structure in precrisis East and Southeast Asia. Journal of Asian Economics, 11(3), 319-331. 
[48] Salas, V. \& Saurina, J. (2002). Credit Risk in Two Institutional Regimes: Spanish Commercial and Savings Banks. Journal of Financial Services Research, 22(3), 203-224.

[49] Šarlija, N., \& Harc, M. (2012). The impact of liquidity on the capital structure: a case study of Croatian firms. Business Systems Research, 3(1), 30-36.

[50] Shaer Biabani, S. G. (2012). Assessment of Effective Factors on Non-Performing Loans (NPLs) Creation: Empirical Evidence from Iran (2006-2011). Journal of Basic and Applied Scientific Research.

[51] Haneef, S., Riaz, T., Ramzan, M., Rana, M. A., Ishaq, H. M., \& Karim, Y. (2012). Impact of risk management on non-performing loans and profitability of banking sector of Pakistan. International Journal of Business and Social Science 3(7) (2012).

[52] Sinkey, J. F. (1992). Commercial bank financial management in the financial services industry: Macmillan New York, NY.

[53] Sorge, Marco (2004). "Stress-testing financial systems an overview of current mythologies." BIS Working Papers No. 165, December. WSEAS Transations on Business and Economics.

[54] State Bank of Pakistan, 2010. Annual Report 2009-10. Available at: http://www.sbp.org.pk/reports/annual/arFY10/MoneyBanking.pdf [Accessed 12 November 2011].

[55] Stiglitz, J. E., \& Weiss, A. (1981). Credit rationing in markets with imperfect information. The American Economic Review, 393-410.

[56] Strischek D. 2000: The Quotable Five C's, Journal of Lending \& Credit Risk Management, 82(7): 47-49.

[57] Weinberg, J. A. (1995). Cycles in lending standards? ECONOMIC QUARTERLYFEDERAL RESERVE BANK OF RICHMOND, 81, 1-18.

[58] Zhang, W. (2011). The role of banks in transition economies: a case study of China with an emphasis on non-performing loans. (C) Wei Zhang. 